\title{
Ambulansesaken - noe å lære av?
}

\author{
Ambulansesaken i Sofienbergparken 6.8. 2007 medførte sterke reaksjoner. Tre år etter hendelsen \\ er det blitt stille i mediene. En mann ble slått ned og fikk alvorlig hodeskade. Han og familien \\ opplevde en tilleggsbelastning da ambulansepersonellet ikke tok ham med. Helsepersonellet \\ som var involvert i hendelsen fikk betydelige psykiske reaksjoner med yrkesskader og langvarige \\ sykmeldinger.
}

\section{Øivind Ekeberg}

oivind.ekeberg@uus.no

Akuttmedisinsk avdeling

Oslo universitetssykehus, Ullevål 0407 Oslo

En mann fra Somalia ble slått ned i parken mens familie og venner var til stede. Ambulanse ble tilkalt kl 1710 og var på stedet kl 1713. Etter en klinisk vurdering ville ambulansepersonellet kjøre ham til legevakten. Etter at pasienten med hjelp hadde reist seg opp, urinerte han på en av ambulansearbeiderne og på bilen. Dette ble oppfattet som viljestyrt og som et atferdsproblem. Ambulansearbeider A sa blant annet «din gris». Ambulansearbeider B sa til en politimann at «nå har toget gått for denne personen». Glasgow Coma Scale (GCS) ble vurdert til 14. Ambulansearbeiderne hadde en klar forståelse av at politiet ville transportere pasienten til legevakten. Kl 1720 reiste ambulansen. Deretter la pasienten seg på gresset, og bildet som senere har versert i mediene ble tatt.

Politiet ringte etter en bil som var egnet for transport av urolige personer. Før denne kom, gikk pasienten inn i en drosje kl 1725. Han gikk selv ut av drosjen og ble registrert på legevakten kl 1735. Kl 1810 ble han tilsett av lege. Kl 1838 bestilte legevakten ambulanse på kode 2 (haster) til Ullevål universitetssykehus. Dette ble oppgradert til kode 1 (akutt) kl 1857. Ambulanse ankom legevakten kl 1903 og sykehuset kl 1913. Etter innleggelsen ble hjerneblødning diagnostisert, og pasienten tilkoblet respirator kl 2300.

\section{Offentlige reaksjoner}

Saken nærmest eksploderte i mediene, og hovedanklagen gikk ut på at pasienten ble nektet behandling som følge av rasisme. Pressens sterke anklager ble raskt understøttet av flere politikere i Stortinget og regjeringen. To ministere iverksatte umiddelbart undersøkelser for å avdekke rasisme i offentlig sektor. En internasjonal gjennomgang av forholdene ved Prehospital divisjon, Ullevål universitetssykehus, avkreftet imidlertid at det forelå rasisme (1). Daværende barne- og likestillingsminister uttalte i november 2007 at det må jobbes mot «rasisme mot nye minoritetsgrupper. Det er nok av eksempler å gripe fatt i. La meg ta to: 1. Drapet på Benjamin Hermansen. 2. Ali Farah-saken» (2). 14 måneder senere uttalte hun at hun aldri hadde ment eller sagt at ambulansesjåførene var rasister (3). Daværende finansminister åpnet valgkampen i august 2007 med å si at dette neppe kunne skjedd med en hvit småbarnsfar i Frognerparken (4) og at ambulansesaken måtte bli et vendepunkt i kampen mot rasisme (5). Ett år senere hadde hun ikke tid til å uttale seg, men uttrykte via sin statssekretær at saker som oppfattes som rasisme, må tas på alvor (3). En tidligere justisminister mente at seksjonsoverlegen og direktøren ved prehospital divisjon var grovt diskvalifisert til å inneha sine stillinger (6).

I de følgende måneder var det mange som mente mye. Et gjennomgående trekk var at det manglet en saklig kronologisk beskrivelse av hendelsesforløpet. Pressen ville ikke trykke bildet som viste at pasienten sto oppreist da ambulansen reiste, men trykte konsekvent det som ble tatt da han lå nede. Saken ble omtalt i flere land. Blant annet uttalte det amerikanske utenriksdepartementet i en gjennomgang av situasjonen i Norge at saken var et eksempel på rasisme i landet (7).

Mange instanser har vurdert saken. Fylkeslegen konkluderte 29.8. 2007 med at det forelå «klart diskriminerende oppførsel som kan forstås med rasistiske overtoner»». Ett år senere uttalte han at han verken hadde uttalt at det var rasisme eller at det ikke var det, men at han holdt døren åpen for endelig vurdering av Statens helsetilsyn (3). Fylkeslegen skrev videre «også i ettertid er det vanskelig å se annet enn at den burde tilsvart umiddelbar transport til UUS og ikke via legevakten» og at ambulansepersonellet heller ikke fulgte gjeldende prosedyre for hodeskade når det gjaldt fiksasjon av hode og nakke inntil skadeomfanget var kjent. Fylkeslegen fant heller ingen opplysninger om at politiet var inneforstått med at det overtok ansvaret for transporten.

Statens helsetilsyn fant 6.2. 2008 ikke klare holdepunkter for at det forelå rasisme, men ga 23.4. 2008 ambulansearbeiderne advarsel for brudd på kravet om forsvarlig og omsorgsfull helsehjelp.

Likestillings- og diskrimineringsombudet tok på eget initiativ opp saken, og konkluderte 26.3. 2008 med at ambulansepersonellet handlet i strid med diskrimineringsloven $\S 4$, blant annet fordi de ikke hadde sannsynliggjort at etnisitet ikke var medvirkende årsak til den dårlige behandlingen (omvendt bevisbyrde). Konklusjonen ble fattet uten å ha snakket med ambulansearbeiderne fordi det angivelig var nok dokumentasjon. Vedtaket ble påklaget til Likestillings- og diskrimineringsnemnda, som 26.2. 2009 konkluderte med at ambulansearbeiderne ikke foretok forskjellsbehandling i strid med diskrimineringsloven $\S 4$.

Spesialenheten for politisaker ila 2.5. 2008 hver av ambulansearbeiderne et forelegg på kr 6000 for utilbørlig opptreden, men ikke for rasisme. Den ene nektet å godta forelegget. Saken kom derfor opp i Oslo tingrett 24.11. 2008, hvor han ble frifunnet. Ordet rasisme ble aldri brukt under rettsforhandlingene. Vitneutsagnene var ofte motstridende.

Journalistene Kjetil S. Østli og Astrid Hexeberg fikk Schibsted Journalism Award for beste fortellende journalistikk for artikkelen «En stemplet mann» i A-magasinet (8), etter at de som de første hadde redegjort for hvordan situasjonen ble opplevd av en av ambulansearbeiderne, over ett år etter hendelsen.

\section{Vurdering av den medisinske skaden} Ambulansepersonellet oppfattet at det forelå en hodeskade med kortvarig bevissthetstap uten åpenbare nevrologiske skader. 


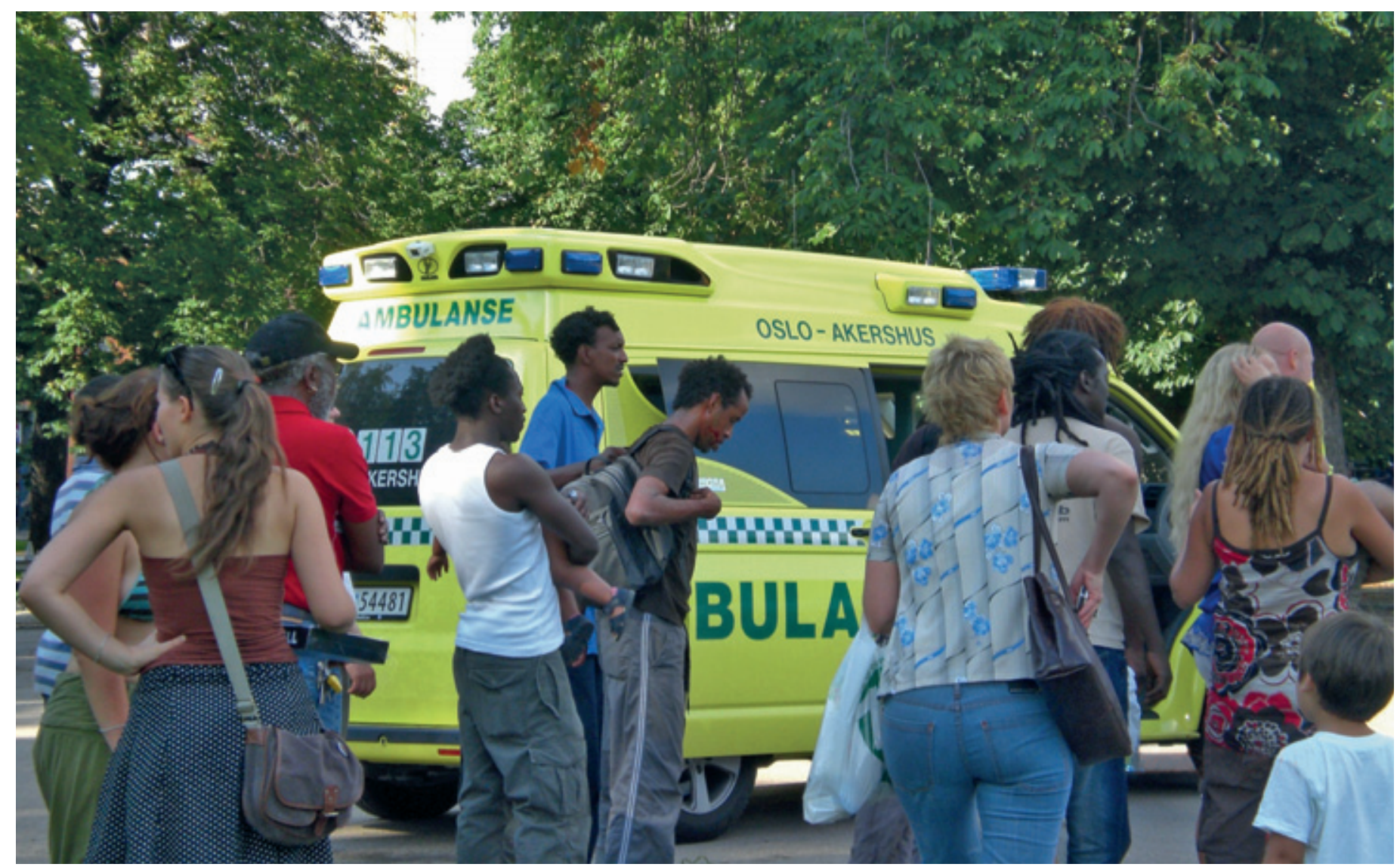

Situasjonen før ambulansen reiste. Foto Øyvind Låte

Derfor ville de kjøre pasienten til legevakten for videre undersøkelse, slik de skriftlige rutinene til sykehuset anbefaler (9). Det er ikke uvanlig at hjerneblødning først gir symptomer etter noe tid. Ambulansearbeiderne stilte ikke denne diagnosen, men trodde det var et atferdsproblem knyttet til rus. Først etter innleggelse i sykehus to timer etter traumet ble diagnosen stilt. Selv om ambulansepersonellet mente at politiet ville ta over transporten, kunne avtalen vært bedre kommunisert og dokumentert. Dette hang sammen med at stemningen var så amper at de fant det best å reise så fort som mulig. De hadde imidlertid en klar oppfatning om at pasienten raskt ville bli transportert til legevakten, og det ble han, fem minutter senere enn han ville blitt med ambulanse.

\section{Medisinske følger av negativ eksponering i mediene}

Flere av helsepersonellet og deres familiemedlemmer har fått langvarige og alvorlige helseplager med langvarige sykmeldinger. Mer enn to år senere var flere av dem ute av stand til å gjenoppta tidligere arbeid. I perioder var tilstanden livstruende. Disse traumene ble forårsaket av en presse som systematisk unnlot å gi et riktig bilde av hva som foregikk i parken, noe som ble forsterket av alvorlige og ensidige påstander fra flere av landets øverste ledere. De ankla- gede fikk ikke forsvart seg, og ble heller ikke forsvart av andre. Dette ble opplevd som et psykisk overfall og en heksejakt. Situasjonen ville trolig vært lettere hvis de hadde blitt trukket for retten, fått fremstilt sine vurderinger, blitt forsvart og fått anledning til å kommentere anklagene, slik det er vanlig i en rettsstat. For tre ansatte er helseproblemene blitt godkjent som yrkesskade.

\section{Medieoffersyndromet}

En form for posttraumatisk stresslidelse (PTSD) er beskrevet som medieoffersyndromet (MOS) (10). Dette er en følge av omfattende kritisk eksponering i medier som rammer personlig integritet og selvbilde. Det blir vanskelig å se TV eller lese aviser fordi det gir sterk gjenopplevelse. Frustrasjon og sinne er også vanlig. Ofte foreligger angst og depresjon, og det kan være risiko for selvmord. Det er økt risiko for medieoffersyndromet hvis man fremstilles som en person med dårlige personlige egenskaper, ved langvarig eksponering, invaderende reportasjer, kontakt i hjem og i fritid, krenkende bruk av bilder, eksponering av andre $\mathrm{i}$ familien, manglende forsvar (arbeidsgiver, fagforening) og unyanserte fremstillinger som preges av korte, repeterte svart-hvitt-beskrivelser. Dette er forhold som i lang tid har preget dem som ble hengt ut i mediene i denne saken.

\section{Hvordan forholde seg etter feil}

Ofte kommer man langt ved å erkjenne og beklage feilen, forklare hvorfor den oppsto og ikke bruke pasienten som trøster hvis det blir vanskelig for en selv. Noen ganger er ikke den som har gjort feilen i stand til, eller i posisjon til, å beklage feilen på en tilfredsstillende måte. Da bør en høyere opp i systemet gjøre dette. Det er fordelaktig med tidlig og personlig kontakt, i hvert fall for å klargjøre at man tar situasjonen alvorlig. Hvis det går lang tid, er det større risiko for at situasjonen låser seg. Jo mer saken kommer i offentlighetens lys, jo større behov er det for at en som er tilstrekkelig høyt oppe i systemet tar denne oppgaven.

\section{Hjelp til ansatte som har gjort feil} Anklagene mot ambulansepersonellet ble også et angrep på sykehuset. Ledelsen på sykehuset forsøkte å forsvare seg ved en pressekonferanse to dager etter hendelsen. Pressekonferanser er i slike situasjoner ikke egnet til å forklare medisinske vurderinger på grunn av taushetsplikten. Pressen kunne uimotsagt sette frem påstander. Mistolkning av medisinske funn kunne heller ikke kommenteres. Kombinasjonen av sterke angrep fra høytstående politikere og en ensidig presse kan bli mer krevende enn det er rimelig å forvente at et sykehus skal mestre uten å hente inn ekstern ekspertise i mediehånd- 
tering. I denne prosessen kan det synes som om ivaretakelsen av de ansatte ikke var god nok. Det var lite kontakt og lite støtte fra sykehusets øverste ledelse, noe som viser hvor vanskelig det kan være å forsvare sykehuset og ansatte samtidig. Sykehusets ledelse og fagforening har et særlig ansvar for å forsvare den ansatte. Sykehuset har en støttegruppe med psykiatrisk, sykepleiefaglig og juridisk kompetanse for ansatte. Støttegruppen var ikke aktivt oppsøkende i den akutte fasen, men ga langvarig oppfølging til dem som tok kontakt. Ved så alvorlige belastninger bør det etter min mening være en mer aktiv tilnærming. Sykehusets ledelse kan komme i en dobbeltrolle overfor en som har gjort feil, da det er vanskelig både å undersøke hva den ansatte har gjort og samtidig å være en støtte for vedkommende. For å sikre at den ansatte fritt kan redegjøre for sin situasjon, har ikke støttegruppen noen rapporteringsplikt til ledelsen.

\section{Diskusjon}

Pasienten ble påført alvorlig hodeskade, noe som har vært en stor påkjenning for ham og hans familie. De fikk en tilleggsbelastning da ambulansen reiste. Det ble gjort feil i Sofienbergparken, både medisinsk og kommunikasjonsmessig. Det må likevel være et rimelig forhold mellom feil og konsekvenser. Helsearbeidere forsøker hele tiden å utvikle sin evne til å handle profesjonelt, selv om de kan bli frustrert og provosert. Enkelte ganger hender det at det renner over for noen.

For helsepersonellet har den offentlige gapestokken og usikkerheten omkring egne arbeidsforhold medført til dels livstruende helseproblemer. Både presse og politikere vet at belastningene ved negativ mediefokusering kan få alvorlige helsemessige konsekvenser. Dette gjelder også personer som aktivt har søkt medienes oppmerksomhet og er vant til å bli eksponert. Her dreier det seg om mennesker som verken har ønsket eller er vant til å bli eksponert i mediene. Da bør det utvises større varsomhet.

Det virker sterkt når mange av landets øverste ledere konkluderer med rasisme. Folk forventer at disse kjenner til en sak før de uttaler seg, og at de snarere bidrar til å redusere problemene enn å forsterke dem. Det var ikke noen saklig og korrigerende instans mellom en ukritisk presse og det amerikanske utenriksdepartementets beskrivelse av forholdene i Norge. I tillegg til den negative medieomtalen ble situasjonen farlig for flere av dem som hadde vært eksponert i mediene. Noen ble på bakgrunn av trusler tilbudt politibeskyttelse og anbefalt å flytte til hemmelig adresse. Ambulanser ble hindret i sitt arbeid til fare for andre pasienter.

På sentrale punkter ble verken fylkeslegens eller likestillingsombudets vurderinger støttet i neste instans, spesielt punkter angående rasisme. Fylkeslegens formulering om rasismespørsmålet ble neppe oppfattet som nøytralt av den vanlige leser. Fylkeslegens uttalelser om at pasienten skulle vært kjørt direkte til sykehus og at det skulle vært foretatt fiksasjon av hode/nakke står i motsetning til ambulanseavdelingens skriftlige rutiner, som ble tilsendt fylkeslegen før hans uttalelser. Rutinene som er basert på felles nordiske anbefalinger fra det nevrokirurgiske miljø, er publisert i Tidsskriftet (11). I henhold til de nordiske anbefalinger skal pasienter med GCS under 9 kjøres direkte til sykehus, altså langt under det som var tilfellet her.

Det er vanlig at ambulansepersonell overlater transporten til politiet. I 2008 loggførte Oslo politidistrikt 2698 henvendelser i kategorien sykdom/psykiatri (12), og det gjelder pasienter fra alle bydeler, samfunnslag og etniske grupper. Politiets logg bekrefter at politiet på stedet tok kontakt med sin sambandssentral for å bestille en spesialbil til transport av pasienten.

Oppfattelsen av denne saken snudde etter at en av ambulansearbeiderne selv ble i stand til å forsvare seg. Han gikk ut i mediene, anket flere vedtak og nektet å vedta forelegget fra Spesialenheten for politisaker, slik at denne endte i retten, hvor det ble mulig å få til en balansert fremstilling. Flere erfarne advokater frarådet dette, ikke på grunn av sakens innhold, men fordi de mente det ville være vanskelig å nå frem i retten etter den massive forhåndsdømmingen i mediene med støtte fra ledende politikere.

Helsepersonell på alle nivåer må kunne forholde seg til utfordrende språkbruk og atferd fra pasienter og pårørende i kriser eller med rus-, atferds- eller kommunikasjonsproblemer. Dette kan være krevende. Det vil alltid bli gjort feil, ikke minst når situasjoner blir følelsesladet. Ved en saklig og nøktern gjennomgang av feil gis det muligheter for læring uten skade. Ved overdrivelser og påstander blir læringen mindre og helseskadene større.

\section{Konklusjon}

Den skadelige effekten av ensidig eksponering i mediene kan medføre en form for posttraumatisk stresslidelse som betegnes medieoffersyndromet. Effekten forsterkes av ensidig kritikk fra autoritetspersoner. Arbeidsgiver og fagforening har et særlig ansvar for å støtte ansatte som eksponeres negativt i mediene. Det må skilles klart mellom å støtte handlingen og å støtte den som har gjort feilen. Når det gjøres feil, kommer man ofte langt ved å beklage og forklare hvorfor det gikk galt. Saker som fokuseres i mediene stiller store krav til kommunikasjon fra ledelsen, både overfor pasienter og pårørende, mediene og ansatte som har gjort feil. Ansatte som har vært utsatt for særlig store påkjenninger, bør tilbys aktiv og oppsøkende helsehjelp.

Oppgitte interessekonflikter: Ingen

Litteratur

1. Evaluering av ambulansetjenesten og AMK, Prehospital divisjon. Oslo: Muusmann Reseach \& consulting, Ullevål universitetssykehus HF, 28.9. 2007.

2. Ramin-Osmundsen M. Norge: Ikke bare idyll. www.regjeringen.no/dep/bld/aktuelt/ taler_artikler/ministeren/ barne og likestillingsminister ramin osm/2007/ norge-ikke-bare-idyll.html?id=492548 (12.5.2010)

3. Østli KS. En stemplet mann. Aftenposten, A-magasinet 3.10.2008

4. Magnus G. Ville neppe hendt hvit småbarnsfar. Aftenposten 10.8.2007.

5. NTB. Ambulansesaken må bli et vendepunkt. Dagbladet 29.8.2007.

6. Holt A. Tragedien i parken. Aftenposten 10.8.2007.

7. US Department of State. Bureau of Democracy, Human Rights and Labor. www.state.gov/g/drl/rls/ hrrpt/2007/100577.htm. (12.5.2010).

8. Ambulansesaken ga Schibsted-pris. Aftenposten 9.5.2009.

9. Medisinsk operativ manual, versjon 6. juni 2007 Oslo: Prehospital divisjon, Ullevål universitetssykehus, 2007

10. Christensen M, Waldahl R, Weisæth L. Medier som skader og dreper. Tidsskr Nor Lægeforen 2007; 127: $3224-7$

11. Sollid S, Sundstrøm T, Kock-Jensen et al. Skandinaviske retningslinjer for prehospital håndtering av alvorlige hodeskader. Tidsskr Nor Legeforen 2008; 128: 1524-7.

12. Rapp OM. Unødvendig ressursbruk. Aftenposten 29.3.2009.

Manuskriptet ble mottatt 13.2. 2010 og godkjent 26.6. 2010. Medisinsk redaktør Mette Sagsveen. 